\title{
Additional Middle Jurassic gastropods from Kachchh (western India) in the collections of the Banaras Hindu University (Varanasi, India)
}

\author{
János SzaBó ${ }^{1} \&$ Anand Kumar JAITLY ${ }^{2}$ \\ ${ }^{1}$ Department of Palaeontology and Geology, Hungarian Natural History Museum, \\ H-1083 Budapest, Ludovika tér 2, Hungary.E-mail: szabo.janos@nhmus.hu \\ ${ }^{2}$ Department of Geology, Banaras Hindu University, Varanasi-221005, India. \\ E-mail: akjaitly@gmail.com
}

\begin{abstract}
Twenty species, new for the faunas from different Jurassic localities of Kachchh, western India are introduced in this paper. Most of these species can be treated by the open nomenclature but some new taxa can also be established on satisfactorily preserved specimens. The new taxa are Jumaramaria jumaraensis n. gen., n. sp., Solarioconulus kachchhensis n. sp., Chartronella belaensis n. sp., Planiturbo lerensis n. sp., Exelissa indiana n. sp., and Sulcoactaeon? haboensis n. sp. With 83 figures.
\end{abstract}

Key words - Gastropoda, India, Jumaramaria, Kachchh, Middle Jurassic, new taxa

\section{INTRODUCTION}

This paper aims to continue increasing taxonomical knowledge of the Middle Jurassic marine gastropod collections from different localities of Kachchh (State Gujarat, western India) stored at the Banaras Hindu University (Varanasi, India). Here, particularly the specimens that are poorly preserved but represent unpublished species are attempted to identify. The major part of this collection has already been published by JAITLY et al. (2000), JAITLY \& SZABó $(2002,2007)$, SZABó \& JAitly (2004), and PANDey et al. (2012).

From the same area, the earliest taxonomical information about Jurassic gastropods was already published in the first half of the $19^{\text {th }}$ century (SOWERBY 1840). However, they had remained out of interest for a long period until papers by Maithani (1968) and Mitra \& Gosh (1979) were published. A more intensive taxonomic activity has recently been started by DAs et al. (1999, 2005, 2018, and 2019), DAs $(2007,2008)$ and Alberti et al. (2013) beside the aforementioned publications. 


\section{LOCALITY, MATERIAL, AND METHODS}

The first paper on this collection (JAITLY et al. 2000) provided detailed information about the geological settings and geographic position of the localities.

A part of the gastropods, discussed in this paper, are from the considerable number of specimens, which have been separated formerly as not or hardly identifiable owing to various reasons such as missing critical shell parts, deformation, risky for cleaning, etc. Another group of specimens were collected during subsequent fieldworks.

The figured specimens are deposited in the Invertebrate Palaeontology Laboratory, Department of Geology, Banaras Hindu University, Varanasi, India.

Figures were prepared using ammonium-chloride coating on the specimens, and the focus stacking method to reach higher quality of them by Helicon Focus Pro 6.8.0 software (https://www.heliconsoft.com).

Abbreviations for the measurements: $\mathrm{H}=$ full height; $\mathrm{HL}=$ height of last whorl; $\mathrm{HP}=$ height of peristome; $\mathrm{D}=$ maximal diameter of shell; $\mathrm{W}=$ width of peristome. Another abbreviation, used in the paper is "dam." to indicate that the given measurements have been taken on damaged shell along the standard lines without reconstruction.

In this paper, the descriptions follow the terminological proposals by KNIGHT et al. (1960) with some slight modifications.

\section{SYSTEMATIC PALAEONTOLOGY}

Class Gastropoda Cuvier, 1795

Subclass Archaeogastropoda Thiele, 1925

Order Vetigastropoda Salvini-Plawen, 1980

Superfamily Pleurotomarioidea Swainson, 1840

Family ?Pleurotomariidae Swainson, 1840

Genus Jumaramaria n. gen.

Type species - Jumaramaria jumaraensis n. sp.

Derivation of name - After the name of the locality, Jumara Dome; remaining part refers to the probable relations.

Diagnosis - Low spired, broadly phaneromphalous, rather rapidly expanding shell with convex whorls. Early whorls evenly arched but last whorl subangular since feebly concave outer face formed below selenizone. Transition to convex base widely rounded angular. Selenizone flush on early teleoconch then increasingly convex. Peristome and aperture nearly radial with abaperturally concave umbilical lip, having narrow, flat frontal face. Shallow collabral undulation vis- 
ible on base. Whole surface ornamented by spiral threads. Growth lines parasigmoidal and orthocline or just prosocline between upper suture and selenizone; prosocyrt between selenizone and periphery; markedly prosocline, straight or shallowly parasigmoidal between periphery and umbilicus.

Remarks - In general, Jumaramaria n. gen. differs from the pleurotomariid genera in formation of the growth lines, which more or less indicate also the shape of the peristome that is incompletely preserved on the available specimen. Jumaramaria n. gen. has parasigmoidal, orthocline or barely prosocline growth lines between the upper suture and the selenizone while other genera of the family have prosocline-prosocyrt growth lines in this area. At the same time, the basal growth lines are strongly prosocline and straight or feebly parasigmoidal in Jumaramaria n. gen. but usually markedly parasigmoidal, frequently sickleshaped, and moderately prosocline in doubtless pleurotomariids.

The shape of Jumaramaria n. gen. shows some similarity to conoidal, nongradate, low or medium high spired genera of Pleurotomariidae like Perotrochus or Mikadotrochus. In both genera, the shape is trochiform, the selenizone is flush, and the angulation with outer face is lacking from the last whorl besides the differences in the growth line form and orientation. In the presence of the rudimentary angulation and outer face on the last whorl, some Laevitomaria species may be similar but the form and orientation of growth lines distinguish them. In Bathrotomaria, the angulation with coinciding selenizone is not restricted to the last whorl but already develop in the early teleoconch. Similarly, some Obornella species may have comparable shape but their peripheral carina or swollen belt at the rim of the base distinguish them.

Distribution - Kachchh, India, Bathonian.

\section{Jumaramaria jumaraensis n. sp.}

(Figs 1-6)

Type specimen - Holotype Inv. No.: BHU2020I 1.

Type locality - Jumara Dome, Kachchh, western India.

Type strata - Jhurio Formation, Bathonian.

Derivation of name - From Jumara Dome.

Diagnosis - Same as for the genus above.

Material - Single, multi-damaged shell.

Measurements $-\mathrm{H}$ dam. $=27 \mathrm{~mm}, \mathrm{HL}=21.6 \mathrm{~mm}, \mathrm{HP}=15.3 \mathrm{~mm}, \mathrm{D}=43$ $\mathrm{mm}, \mathrm{W}$ dam. $=23.5 \mathrm{~mm}$, pleural angle: $113^{\circ}$.

Description - The available specimen has a rather low turbiniform, rapidly expanding shell of convex whorls, which have no angulation between the pairs of sutures on the early teleoconch. Last whorl joins to the base through a widely 
rounded angulation that is followed by the suture on former whorls. On the last whorl, the area between the selenizone and the rim of the base becomes slightly concave so a narrow, obscure outer face develops in the latest growth phases. The selenizone itself runs below the mid-whorl; it is rather wide along the whole shell. Its surface is flat on the early teleoconch then changes into convex. The suture is impressed and it is accompanied abapically by an upward bent, narrow belt of the shell, which causes a shallow, subsutural concavity of the whorl surface. The base is flattened as a whole with a moderately convex wall, and has a broad umbilicus. Rim of the umbilicus is also widely rounded angular. The peristome is incompletely preserved but the remnants indicate an abaxially elongated aperture that is almost in radial position as the form of the growth lines suggests it. Its parietal lip appears as the edge of thin shell enamel; the umbilical lip is slightly thickened and backward oriented from the parietal wall towards the basal lip; it has also a narrow outer face and a wide, shallow sinus between the parietal and basal lip.

Spiral ornament of the shell consists of threads on the whole surface of the shell, including also the selenizone. On the last whorl, the selenizone bears three threads beside its edges, which appear also as threads where not damaged. These spiral threads are nearly equally strong almost everywhere, except the subsutural area where thinner and stronger threads alternate. Much thinner and somewhat denser threads cross the spiral ones collabrally on the whorls and form together a characteristic network. In the basal region, only differently strong growth threads and striae cross irregularly the spiral threads. Shallow, collabral surface undulation is also observable on the base; it is clearer in the parietal region.

The growth lines are orthocline or just barely prosocline, and slightly parasigmoidal between the adapical suture and the selenizone, orthocline and strongly prosocyrt between the selenizone and the obscure angulation at the abaxial rim of the base; strongly prosocline and almost straight or barely parasigmoidal on the base.

Remarks - No other species, fitting with the description of the genus has been found.

Occurrence - Jumara Dome, Jhurio Formation, Bathonian.

Superfamily Ataphroidea Cox, 1960

Family Ataphridae Cox, 1960

Genus Solarioconulus Cossmann, 1918

Type species - Trochus nudus Münster, 1841

Solarioconulus kachchhensis n. sp.

(Figs 7-11) 
Type specimen - Holotype Inv. No.: BHU2020I 2.

Type locality - Habo Dome, Kachchh, western India.

Type strata - Chari Formation, Callovian.

Derivation of name - From name of the larger locality area.

Diagnosis - Turbiniform shell with low protoconch and convex whorls. Suture impressed and abapically accompanied by belt of concavity, widening on last whorl as narrow ramp with indistinct outer rim. Last whorl slightly expanding and downward turning. Base convex, phaneromphalous. Peristome strongly prosocline, interrupted at suture, thin in parietal region and reflecting over umbilicus.

Material - Single shell with dense traces of ramifying borings on latest whorls. Measurements - Inv. No.: BHU2020I 2; $\mathrm{H}=17.7 \mathrm{~mm}, \mathrm{HL}=14 \mathrm{~mm}, \mathrm{HP}=$ $9.8 \mathrm{~mm}, \mathrm{D}=16.4 \mathrm{~mm}, \mathrm{~W}=9 \mathrm{~mm}$, apical angle: $93^{\circ}$, pleural angle: $82^{\circ}$.

Description - A turbiniform shell is available that has blunt apex, moderately convex whorls and a convex base. The initial chamber of the protoconch just feebly rises above the first, almost planispiral whorl then the coiling rapidly changes into clearly trochospiral. Teleoconch whorls are initially almost flat then increasingly convex; from the penultimate whorl, a narrow and shallow concave belt is formed subsuturally; the suture is slightly impressed. Base as a whole and also its wall are convex with arched transition towards the outer whorl surface; a narrow umbilicus with rounded rim is present. Near the peristome, the last whorl slightly deviates downward, and the subsutural concave belt widens as a ramp without distinct abaxial rim. The peristome is suborbicular, prosocline and tangentially joins to the last whorl. Its parietal lip appears as thin callosity, the other parts are rather thick but outward tapering. The umbilical lip and the adaxial part of the basal lip form a narrow, lunuliform and feebly concave outer face.

The shell is smooth, some marked collabral ridges appear only near the peristome but they may have been grown during reparation of a shell damage. The growth lines are very fine, like in other ataphrids; actually, some pieces are observable only partly owing to a dense network of a shallow boring system on the surface of the shell.

Remarks - Morphology of the available specimen well matches with the diagnosis of Solarioconulus Cossmann, 1918. The main difference from the type species is that it has acute, feebly coeloconoidal early whorls, which are simply conoidal in the Kachchh species. The shell is very similar also to Buckmanina Cossmann, 1920 but the thickened peristome, which is continuous also at the parietal part, distinguishes it. The morphology of these genera is close to those of some ataphrid genera, which explains the opinion about the family attribution.

Occurrence - Habo Dome, Chari Formation, Callovian. 
Superfamily Trochoidea Rafinesque, 1815

Family Paraturbinidae Cossmann, 1916

Genus Chartronella Cossmann, 1902

Type species - Chartronia digoniata Cossmann, 1902

Chartronella belaensis n. sp.

(Figs 12-16)

Type specimens - Holotype Inv. No.: BHU2020I 3.

Type locality - Bela Island, Kachchh, western India.

Type strata - Chari Formation, Callovian.

Derivation of name - From the name of the type locality.

Diagnosis - Low spired shell of rapidly expanding whorls. Suture deeply impressed. Last whorl tricarinated with markedly concave interspaces. Lowermost carina hidden on former whorls under suture in deep furrow. Last whorl downward deviating near final peristome, being strongly prosocline and slightly thickened.

Material - Single, fragmentary, and strongly worn specimen; a part of the peristome and large connected parts are lacking from the base.

Measurements - Inv. No.: BHU2020I 3; $\mathrm{H}$ dam. $=5.5 \mathrm{~mm}, \mathrm{D}$ dam. $=8.8$ $\mathrm{mm}$, pleural angle: $102^{\circ}$.

Description - The specimen on hand represents a low spired species with a tricarinate last whorl and a strongly convex, anomphalous base, having slightly convex wall. Between pairs of the carinae, deep, concave belts are formed. The lowermost carina is overlapped on the spire whorls by the suture and the accompanying uppermost carina. The suture itself seems rather deeply impressed. The adapical concave belt widened and the last whorl considerably deviated abapically in the last growth phase so the latest peristome became extremely prosocline. The remnants indicate its subcircular shape; the preserved parietal and basal peristome parts are slightly thickened internally.

A small area of the outer face on the last whorl preserved the ornament of very thin, rather sparse spiral threads.

Remarks - In spite of the poor preservation, the specimen well shows some characters, which distinguish it from the formerly published Chartronella species. The Bathonian Trochus obtusus Rigaux et Sauvage, 1869 is the most similar

Figs 1-16. Species of Vetigastropoda - Figs 1-6. Jumaramaria jumaraensis n. gen., n. sp. - 1-4. Apical, basal, abapertural, and apertural views, $\times 1.4$. -5 . Details of the ramp at higher magnification, $\times 2.5$. -6 . Details of the selenizone ornament, $\times 4$.4. - Figs 7-11. Solarioconulus kachchhensis n. sp., holotype. - 7-10. Abapertural, apical, apertural, and basal views, $\times 2$. - 11. Magnified view of a boring system from the last whorl, $\times 3$. - Figs 12-16. Chartronella belaensis $\mathrm{n}$. sp. holotype. 12-15. Abapertural, apertural, apical, and basal views, $\times 3.4$. -16 . Details of shell part with spiral ornament remnants, $\times 11$ 

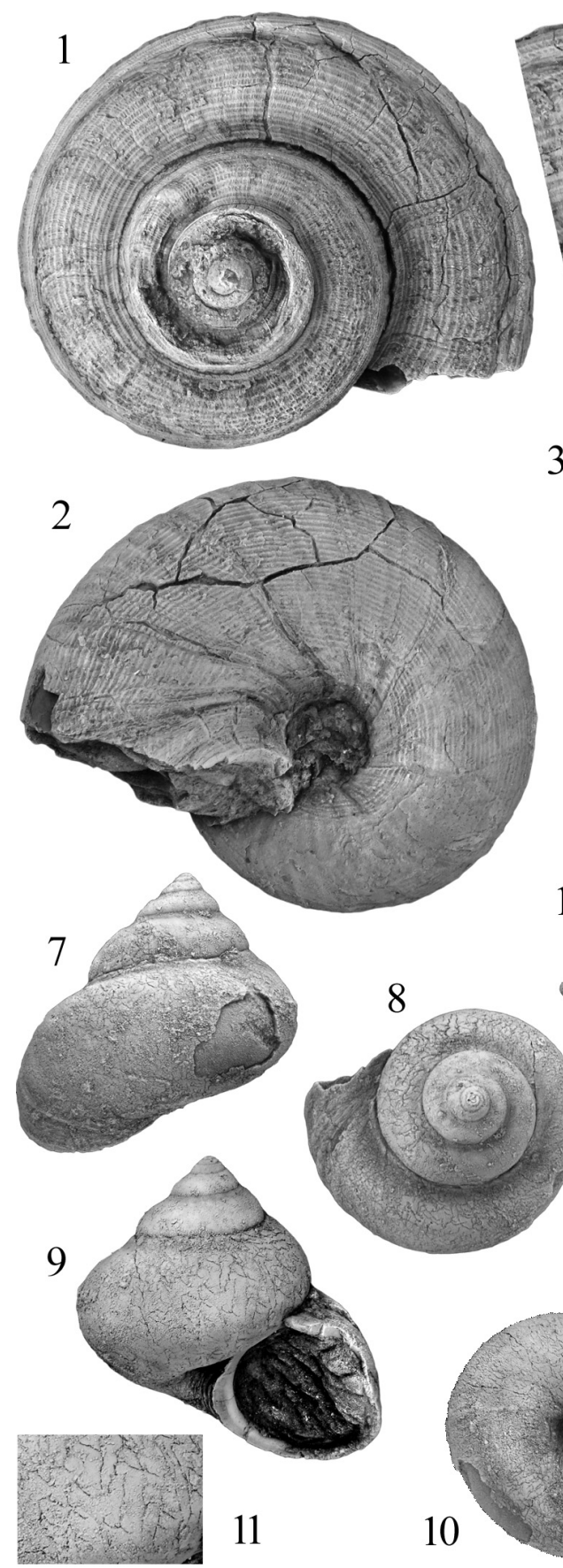
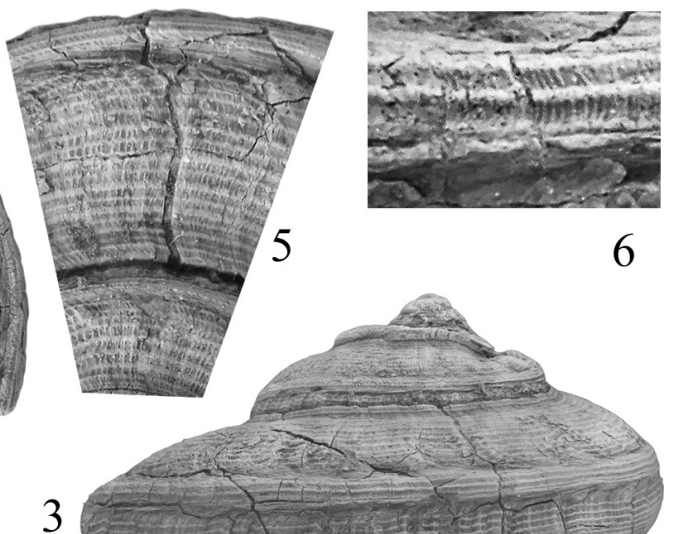

6

3

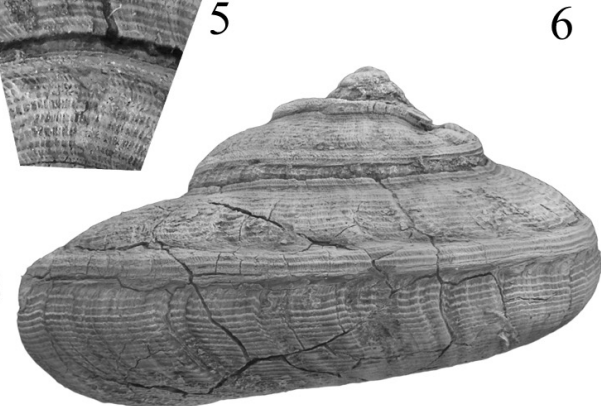


to the Kachchh specimen. It has also a rather low spire, comparable size, a blunt apical region and an ornament of delicate spiral threads, however, the interspaces between pairs of the carinae are much less concave; the carinae themselves are much weaker than in Chartronella belaensis n. sp.

Occurrence - Bela Island, Chari Formation, Callovian.

Family Metriomphalidae Gründel, Keupp et Lang, 2017

Genus Planiturbo J.-C. Fischer, 1969

Type species - Turbo planispira Cossmann, 1885

Planiturbo lerensis n. sp.

(Figs 17-28)

Type specimens - Holotype Inv. No.: BHU2020I 4; paratype Inv. No.: BHU202015.

Type locality - Near Ler, Kachchh, western India.

Type strata - Upper Chari Formation, Callovian.

Derivation of name - From the name of village Ler.

Diagnosis - Shells of about five dextral whorls, initial ones discoidally coiled, resulting concave apex. Trochospiral coiling started from third whorl with convexly arched surface. Base slightly less convex than last whorl, transition between them widely arched. Moderately broad umbilicus with angular basal rim present. Aperture suborbicular, peristome continuous with thick parietal part. Ornament of several subequally spaced, strong, nodulose carinae, starting from third whorl. Transverse ornament of collabral riblets between pairs of carinae. Growth lines appearing like thin threads.

Material - Two multi-damaged specimens; the shell remnants are strongly fragmented on the surface of porous infilling sediment; their further cleaning would be too risky.

Measurements - Inv. No.: BHU2020I 4; H dam. $=9.6 \mathrm{~mm}, \mathrm{D}$ dam. $=10.8$ $\mathrm{mm}$; Inv. No.: BHU2020I 5; H dam. $=9.3 \mathrm{~mm}, \mathrm{D}$ dam. $=10.7 \mathrm{~mm}$.

Description - Shells consist of 4.5 to 5 whorls; the earliest 2.5 to 3 ones are coiled in dextral discoidal way so they form broad, slightly concave apical area. In this shell region the whorls are flat and sharply angular along the abaxial suture; the suture itself is flush here. From the third whorl, the coiling gradually alters into trochospiral; the abaxial angulation becomes increasingly rounded then the whole whorl surface changes into convexly arched. The last whorl turns into the less convex base through a rather wide arch. A rather broad umbilicus with angular rim and almost cylindrical inner wall is observed in both specimens. From the peristome, only the parietal lip is preserved; it consists of a thick, smooth shell 
layer and a part of an inner, possibly circular, thickening along the basal edge. The shell remnants are indicative of a suborbicular aperture and a prosocline, entire peristome with wide "V"-shaped inner lip and largely arched outer lip with tubular nodules or spines as terminal processes of the carinae.

From the terminal half of the second coil, single swollen spiral belts start along both sutures, which have been formerly flush. Soon spirally elongate nodules appear on these swellings. From the third whorl, the swollen belts become nodosed carinae. Between them, subregularly repeated, sparse, feebly prosocline, collabral ribs develop. From the fourth whorl a third carina also appears halfway between the former ones then the number of carinae gradually increases to 5 or 6 for the last growth phase. In addition, four similar carinae are present also on the last base; one is just at the rim of the umbilicus. The early ribs become unequally thinner and denser from the beginning of the fourth whorl; these sharp riblets remain the transverse ornament of the succeeding whorls and the base. The growth lines are fine but sometimes as marked as thin threads, which are much weaker and denser than the riblets.

Remarks - Comparable species from Bathonian strata is published by CossMANN (1885) as Turbo planispira (1885, p. 262, Pl. VII, figs 43-46). FisCHER, J.-C. (1969) designated it as the type species for genus Planiturbo. The specimens from Ler are similar to the type species but the differences support their new species status: the early, markedly ribbed whorl part, following the planispiral portion, is lacking from the type species just like the thin riblets on the subsequent whorls and the base of Planiturbo lerensis n. sp. The nodules of P. lerensis $\mathrm{n}$. sp. are much smaller on the base than in P. planispira and this seems to be true also for the nodes of the whorls that are poorly preserved.

Occurrence - Ler, upper Chari Formation, Callovian.

Subclass Neritimorpha Golikov et Starobogatov, 1975

Superorder Cycloneritimorpha Bandel et Frýda, 1999

Superfamily Neritoidea Rafinesque, 1815

Family ?Neritopsidae Gray, 1847

Subfamily ?Colubrellopsinae Bandel, 2007

Genus ?Colubrellopsis Bandel, 2007

Type species - Naticella acuticostata Klipstein, 1843

Colubrellopsis? sp.

(Figs 29-30)

Material - Single, damaged specimen; peristome is not cleanable.

Measurement - Inv. No.: BHU2020I 6; D = $4.1 \mathrm{~mm}$. 


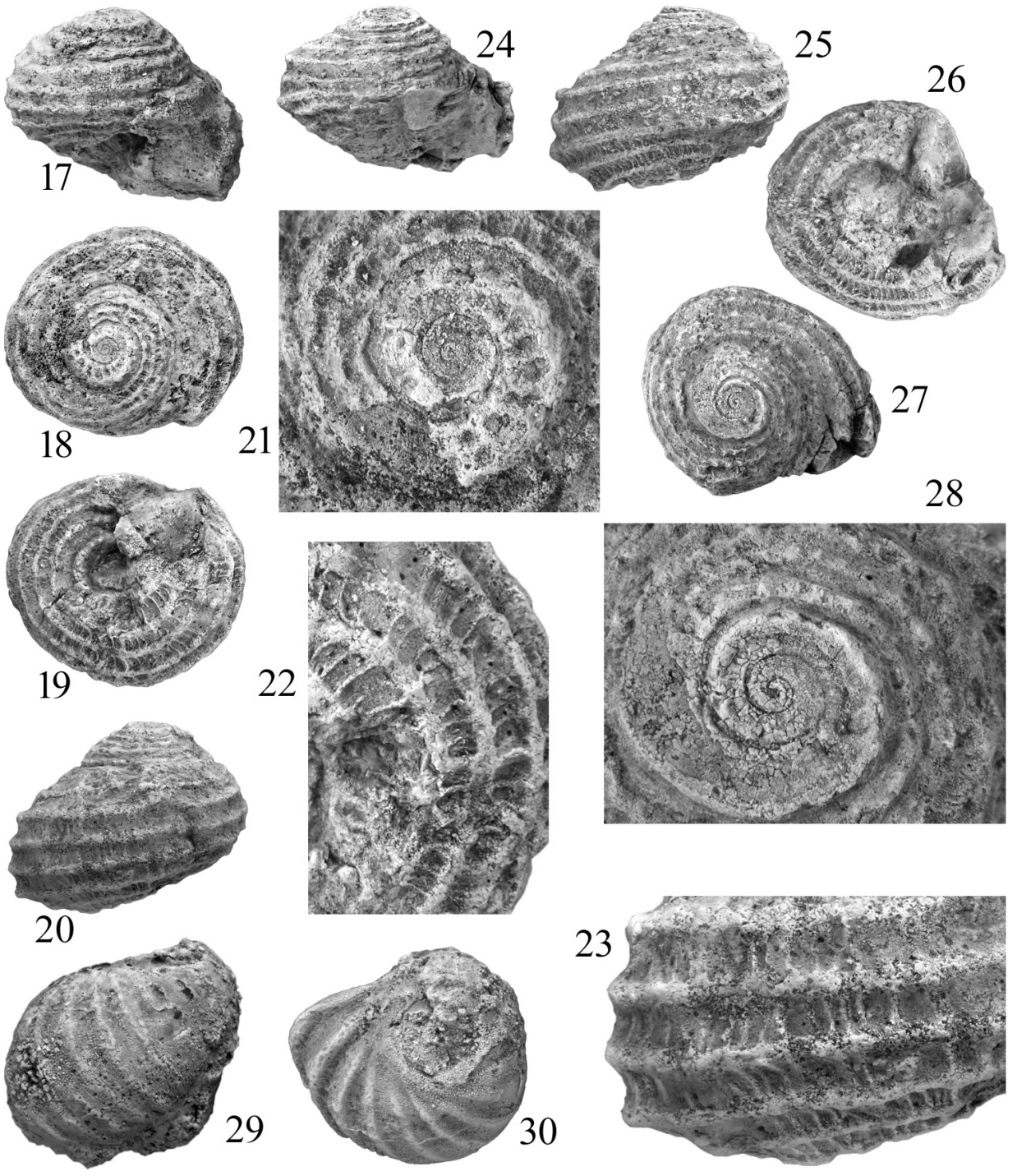

Figs 17-30. Species of Vetigastropoda, and Neritimorpha. - Figs 17-23. Planiturbo lerensis n. sp., holotype. - 17-20. Apertural, apical, basal, and abapertural views, $\times 2.8$. -21 . Details of the early shell, $\times 9$. -22 . Details of the basal ornament, $\times 7.6$. -23 . Details of the last whorl ornament, $\times 7$. Figs 24-28. Planiturbo lerensis n. sp., paratype. - 24-27. Abapertural, apertural, basal, and apical views, $\times 2.8$. -28 . Details of the earliest whorls, $\times 10.3$. - Figs 29-30. Colubrellopsis? sp., abapertural, and apical views, $\times 7.3$ 
Description - The only specimen is the last whorl of a small neritiform shell; the earliest whorls seem fully lacking but a small, uncertain shell remnant on the inner mould suggests non-dissolved inner parts of the penultimate whorl. The peristome and aperture are subaxially elongated and shows lunuliform outline. Outer lip is thickened externally; inner lip is not accessible. The thickenings of the outer lip have been periodically repeated so the available last whorl is rather densely ribbed between the suture and the axial region of the base. The ribs, and consequently the outer lip, are fairly prosocline, slightly prosocyrt; the apertural plane is nearly tangential to the last whorl.

Remarks - The inferred shell remnant seems to be the basal region of the penultimate whorl; its presence suggests belonging of this species to Neritopsidae. The genus of most similar outer morphology is Colubrellopsis (Colubrellopsinae) but the characters of the ribs are different; that is why the question mark is necessary after the genus name.

If that shell remnant were a random shell piece in realistic position, the species would be a neritoidean one. Actually, other specimens are necessary to a right identification.

Occurrence - Sadhara, Patcham Island, Eomiodon Redstone Member, Bajocian.

Subclass Caenogastropoda Cox, 1959

Superfamily Loxonematoidea Koken, 1889

Family ?Zygopleuridae Wenz, 1938

Genus ?Zygopleura Koken, 1892

Type species - Turritella hybrida Münster, 1841

Zygopleura? sp.

(Figs 31-33)

Material - Two damaged specimens, a single whorl fragment, and a longer shell part with poorly preserved last whorl are available on the same rock surface. The protoconch, the early teleoconch and the peristomal regions are lacking. The remnants are probably outer casts.

Measurements - Inv. No.: BHU2020I 7; H dam. $=6.7 \mathrm{~mm}$.

Description - The shell is turriculate with convex whorls that are separated by slightly impressed suture. A narrow, flush belt of the whorls accompanies the suture abapically but the adapical side is convex. The complete shell seems to reach fifteen or more whorls length.

Clearly opisthocline and barely parasigmoidal, suture-to-suture ribs of periodical repetition ornament the shell. No other ornament, neither growth lines are visible. 
Remarks - Amongst the zygopleurid genera, this kind of teleoconch ornament may appear in different growth phases; less damaged specimens are needed to precise identification.

Occurrence - Jhura Dome, Chari Formation, Callovian.

Superfamily Cerithioidea Fleming, 1822

Family Procerithiidae Cossmann, 1906

Subfamily Procerithiinae Cossmann, 1906

Genus ?Procerithium Cossmann, 1902

Type species - Procerithium quinquegranosum Cossmann, 1902

Procerithium (Rhabdocolpus)? aff. lorieri (Hebert et Deslongchamps, 1860)

(Figs 34-35)

aff. 1860 Cerithium Lorieri Hebert et Deslongchamps - p. 192, Pl. 6, Fig. 2a, b.

aff. 1913 Procerithium (Rhabdocolpus) Lorierei (Hebert et Deslongchamps, 1860) - Cossmann, p. 77, Pl. 4, Figs 42-43.

Material - Single specimen without earliest latest shell parts.

Measurements - Inv. No.: BHU2020I 8; H dam. $=11.5 \mathrm{~mm}, \mathrm{D}=4.5 \mathrm{~mm}$.

Description - Nine teleoconch whorls of a high turriculate shell represent this species. All whorls are convex and a rather deeply impressed suture separates them; the suture itself is like a thin groove between two thin threads. Along its both sides, narrow ramps developed on the early whorls with a wider, flattened outer face between them. This biangular whorl surface gradually changes into almost evenly arched during the growth. Base seems conoidal as a whole with markedly convex wall that has a flattened belt next the periphery. Approaching the axis, the basal wall changes into a neck like axial process that is not fully preserved but suggests presence of a siphonal protrusion. No peristome part is preserved.

On the earliest part of the available shell fragment, three cords mean the spiral ornament beside the single spiral threads along both sides of the suture. Subsequently, the formerly supra-sutural thread adapically shifts and strengthens while a new thread appears closely above the suture. Sparse, collabral ribs cross the cords; they terminate at the sutural threads. The ribs are similarly strong like the cords but less sharp. The two ornamental elements form a network, with small, pointed nodes only along the earliest three spiral cords. The shape of the ribs and the growth lines are slightly opisthocyrt, besides, they are slightly opisthocline on the earliest visible whorls but orthocline on the last whorls.

Remarks - Key shell parts, the apical whorls and the peristome, are lacking for a perfect identification. This single, fragmentary teleoconch is similar to the same shell part of Cerithium lorieri Hebert et Deslongchamps, 1860 (Bathonian) but dif- 
ferent in the concave wall of the base. CossmanN (1906) identified this species as Procerithium Cossmann, 1902 in P. (Rhabdocolpus) subgenus (Cossmann 1913).

Occurrence - Ler, Chari Formation, Callovian.

Genus Diatrypesis Tomlin, 1929

Type species - Cerithium guerrei Hebert et Deslongchamps, 1860

Diatrypesis sp. 1

(Fig. 36)

Material - Single, incomplete specimen is available, partly embedded on rock surface. Protoconch and latest whorl(s) are lacking.

Measurements - Inv. No.: BHU2020I 9; $\mathrm{H}$ dam. $=20.3 \mathrm{~mm}, \mathrm{D}$ dam. $=5.3$ $\mathrm{mm}$, pleural angle: $20^{\circ}$.

Description - Shell is rather highly turriculated; ten whorls with impressed suture represent this species. Surface of the whorls has a profile that is characteristic for the teleoconch of Diatrypesis: a marked carina just below the suture, accompanied by a shallow concavity abapically, and a wider, convex area below it. The convex area forms also the periphery of the whorls; the latest whorl smoothly turns into the base. The broken surface of the last whorl shows cross-section of a siphonal outlet in its axial area.

The early whorls are collabrally ribbed between the lower suture and the subsutural carina that is sparsely nodosed. The ribs gradually shorten and weaken during the growth but the nodulae of the carina persist along the entire shell. Dense, fine threads mean the spiral ornament on the visible whorls.

The growth lines and the ribs are opisthocline, and slightly opisthocyrt in the abapical half of the early whorls; the opisthocyrt form almost fully disappears for the latest whorls.

Remarks - Diatrypesis sp. 1 differs from most of the formerly published species in its less markedly ornamented nature. Most of these species are ribbed even on the last whorls differently from Diatrypesis sp. 1. In the unribbed latest whorls, the Bajocian Diatrypesis angulocostatum (Szabó, 1983) is similar to Diatrypesis sp. 1, however, it has flush last whorls and the subsutural carina (cord) is without nodules but densely crossed by tiny riblets.

Occurrence - Jumara Dome, Patcham Formation, Bathonian.

\section{Diatrypesis sp. 2}

(Figs 37-40)

Material - Two fragmentary and worn specimens of 5-5 whorls without earliest and latest shell parts. 
Measurements - Inv. No.: BHU2020I 10; $\mathrm{H}$ dam. $=10.7 \mathrm{~mm}, \mathrm{D}$ dam. $=5.3$ $\mathrm{mm}$, pleural angle: $22^{\circ}$; Inv. No.: BHU2020I $11 ; \mathrm{H} \mathrm{dam} .=9.5 \mathrm{~mm}, \mathrm{D}$ dam. $=4.6$ $\mathrm{mm}$, pleural angle: $22^{\circ}$.

Description - With their partly preserved base, both specimens seem to represent latest growth phase of a species, having turriculate shell of conoidal outline. The whorls are almost flush but a shallow concave zone follows the subsutural carina that shifts into low convex surface in abapical half of the whorl; the convexity continues towards the base on the last whorl. The suture is sharply impressed.

The subsutural carina bears rather marked nodes; dense, very fine spiral threads complete the spiral ornament. Dense, thin, collabral riblets cover the early preserved whorls; they gradually vanish during the growth and lack from the latest whorls. The growth lines and the riblets are markedly opisthocline, and opisthocyrt. The abapical part of the growth lines approaches the direction of the spiral lines in the peripheral/outer base area.

Remarks - The coiling angle does not differ significantly from that measured in Diatrypesis sp. 1, but the whorls are slightly lower and less convex; they are also ribbed in early growth phases then the ribs disappear and the nodules of the subsutural carina persist also on the whorls without ribs. However, the ribs, as well as the growth lines, are more opisthocline and more opisthocyrt than in Diatrypesis sp. 1.

Diatrypesis sp. 2 seems closely related to that one, which represents Diatrypesis sp. 1 . They may belong to a single evolutionary lineage or just to a single species of unknown (high) variability.

Occurrence - Keera Dome, Chari Formation, Callovian.

Diatrypesis? sp.

(Figs 41-42)

Material - Single, slightly flatten teleoconch fragment with eroded shell remnants.

Measurements - Inv. No.: BHU2020I 12; $\mathrm{H}$ dam. $=23.6 \mathrm{~mm}$, pleural angle: $\sim 14^{\circ}$.

Description - Plan of the shell is similar to those of Diatrypesis sp. 1 and sp. 2 above, however, the subsutural carina is represented here by a low, ribbon like elevation without nodules. Sparse, rather strong, straight, sharp ribs cross the whorls on the earliest preserved whorl from suture to suture; on this shell part, their orientation is slightly opisthocline. On the following whorls, the ribs become orthocline and less marked.

Remarks - The differences in the morphology from the above Diatrypesis species may hold generic level taxonomic meaning; however, the state of preservation does not allow to clarify it.

Occurrence - Jumara Dome, Jhurio Formation, Bathonian. 
Family Cryptaulacidae Gründel, 1976

Subfamily Exelissinae Guzhov, 2004

Genus Exelissa Piette, 1860

Type species - Cerithium strangulatum d' Archiac, 1843

Exelissa indiana n. sp.

(Figs 43-59)

Holotype - Inv. No.: BHU2020I 13.

Paratypes - Inv. Nos: BHU2020I 14-20.

Type locality - Khadir Island near Gadhada village.

Type strata - Gadhada Formation, Lower Callovian.

Derivation of name - Modified from India.

Diagnosis - Small shells of turriculate spire with just detectible cyrtoconoidal outline. Full grown shells consisting of 9 to 12 whorls, separated by furrow of V-shape cross-section with suture in the deepest line. Outer face of whorls flattish between two sutural furrows. Last whorl downward and leftward tending, last peristome subcircular, trumpet-like. Ornament composed of sparse, collabral riblets and dense, differently strong spiral threads. Shell shape and ornament highly variable.

Material - 278 more or less incomplete specimens in addition to the types below (Inv. No.: BHU2020I 21-299).

Measurements - BHU2020I 13; Holotype: $\mathrm{H}$ dam. $=7.7 \mathrm{~mm}, \mathrm{D}=2.2 \mathrm{~mm}$ (Figs 43-45); BHU2020I 14; Paratype1: $\mathrm{H}$ dam. $=9.8 \mathrm{~mm}, \mathrm{D}=2.7 \mathrm{~mm}$ (Figs 48-49); BHU2020I 15; Paratype2: $\mathrm{H}$ dam. $=10.1 \mathrm{~mm}, \mathrm{D}=2.5 \mathrm{~mm}$ (Figs 56-58); BHU2020I 16; Paratype3: $\mathrm{H}$ dam. $=9 \mathrm{~mm}, \mathrm{D}=2.7 \mathrm{~mm}$ (Figs 54-55); BHU2020I 17; Paratype4: $\mathrm{H}$ dam. $=9.5 \mathrm{~mm}, \mathrm{D}=2.5 \mathrm{~mm}$ (Figs 52-53); BHU2020I 18; Paratype5: $\mathrm{H}$ dam. $=7.8 \mathrm{~mm}, \mathrm{D}=2.4 \mathrm{~mm}$ (Figs 46-47); BHU2020I 19; Paratype6: $\mathrm{H}$ dam. $=7.5 \mathrm{~mm}, \mathrm{D}=2.1 \mathrm{~mm}$ (Figs 50-51); BHU2020I 20; Paratype7: $\mathrm{D}=2.4$ $\mathrm{mm}$ (Fig. 59).

Description - Shells are rather highly turriculate with slightly pupiform outline. The teleoconch whorls are separated by deeply impressed suture, running in $\mathrm{V}$-shaped furrow with angular rims. The wide outer face between the angulations is barely convex to barely concave. Base as a whole is convex with just convex wall; it joins to the outer face through the lower angulation that becomes rounded for the last whorl. The former coiling mode changing during formation of the last whorl; growing turns downward while the sutural furrow widens. The peristome, which is sub-quadrangular in earlier growth phases, changes into subcircular and its plane turns abaxially about $70^{\circ}$ from the former position beside increasing in its prosocline orientation. In its final form, the peristome is trumpet-like, and far 
extending left from the axis. The latest parietal and columellar lips are most commonly detached from the basal shell parts.

The shape of the growth lines is variably opisthocyrt between the almost straight to clearly arched degrees; their orientation is also changing between slightly prosocline to slightly opisthocline. This variability appears mainly between different specimens but sometimes also between whorls of a single specimen. The last whorl modifications result every time in marked prosocline growth line orientation. The teleoconch whorls are ornamented by sparse collabral ribs and differently strong spiral threads. Following the apparently smooth protoconch, not found in entire form, the ornament starts with single threads on angulations, which limit the outer face; they are crossed by few (7-8) riblets/ whorl; third spiral thread appears on the next whorl between the former ones. The number of the spiral threads increase for the last whorl to ten or little more; the number of the ribs on the same whorl reaches $12 \pm 1-2$. The two primary threads, running on the angulations, become cord during the growth; the other threads remain thinner but variable in strength. The base is covered only with spiral threads. The ribs are nodosed at intersections with the primary threads/ cords and sometimes also at the other threads. Frequently, the ribs are rudimentarily developed but in a highly variable way: like nodes only at rims of the outer face, as shallow undulation, or fully lacking from shell parts, etc.

Remarks - In distinction of the early cerithiform genera, key importance has been attributed to the morphology of the protoconch. Amongst the available abundant specimens, no entire early shell has been found. However, the observable earliest whorl, which may be part of the protoconch, is bicarinate in several specimens. By GuzHOv (2004) modified diagnosis, the last protoconch whorls

Figs 31-59. Caenogastropods 1. - Figs 31-33. Zygopleura sp. - 31. Both specimens, ×5.5. - 32. Details of the earliest preserved whorls, $\times 13.5$. -33 . The last whorl specimen from upper left corner of Fig. 31, $\times 7$. - Figs 34-35. Procerithium (Rhabdocolpus)? aff. lorierei (Hebert et Deslongchamps, 1860). - 34. Full view, $\times 3.3$. - 35. Magnified details, $\times 7$. - Fig. 36. Magnified "best" view of Diatrypesis sp. 1, ×3.8. - Figs 37-40. Diatrypesis sp. 2. - 37-38. BHU2020I 10 specimen. - 37. Side view of full remnant, $\times 3.7$. -38 . Details of pattern on the same specimen, $\times 7 .-39-40$. BHU2020I 11 specimen. -39 . Side view of full remnant, $\times 4.2$. -40 . Riblets on the earliest whorl of the same specimen, $\times 7$.2. - Figs 41-42. Diatrypesis? sp. - 41. "Apertural" view of the available, flattened specimen, $\times 1$ 1.7. - 42. Side view, $\times 1.7$. - Figs 43-59. Exelissa indiana n. sp. - 43-45. Holotype. - 43-44. Apertural, and abapertural view, $\times 4$. -45 . Ornament details of the holotype in $\times 7.8$ magnification. The holotype in Figs 43-44 and six paratypes (BHU2020I 14-19) in Figs 46-59 are equally magnified $(\times 4)$ to demonstrate the high size variability among the full-grown shells. The same shells well show also the high shape, and ornament variability. The photo in Fig. 58 (BHU2020I 19) is taken parallel to the most frequent final peristome plane, $\times 6$. - Fig. 59. Perpendicular view to the plane of the trumpet like peristome, $\times 6.2$. Detailed data between the figures, the measurements, and the inventory numbers of the types are supplied above, in the species description 

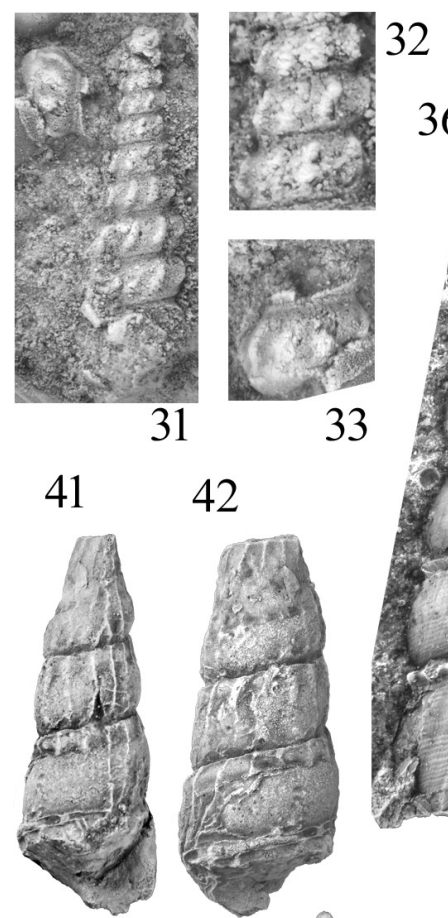

42
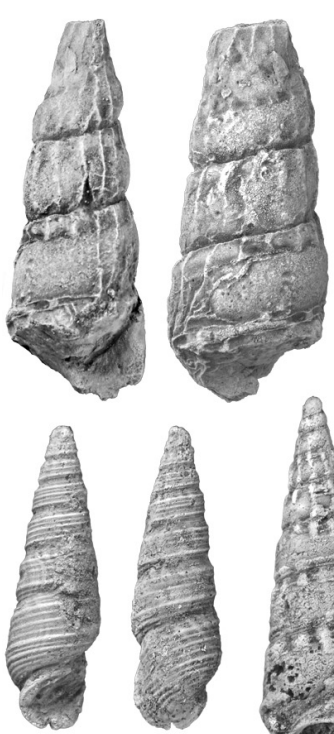

46

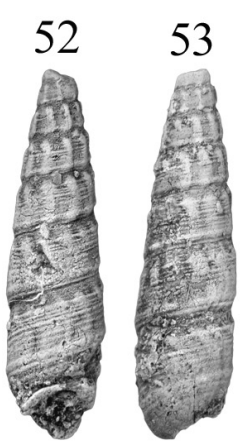

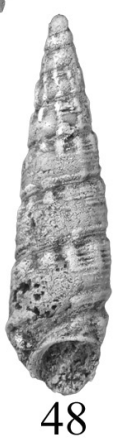

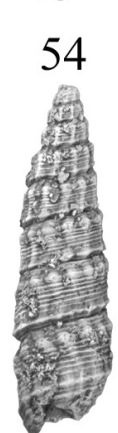

33
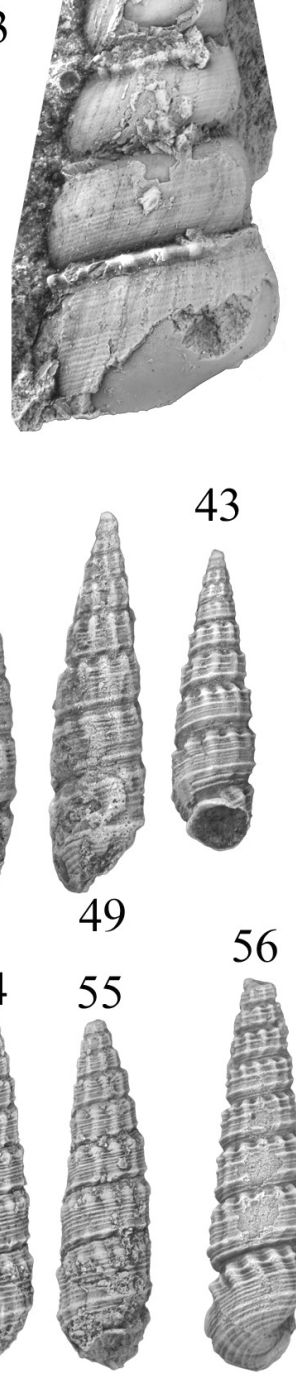
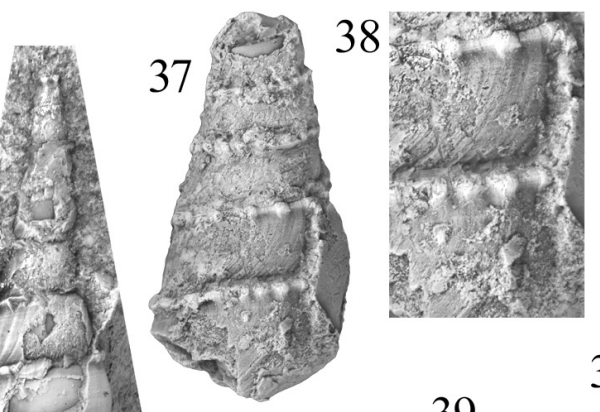

34

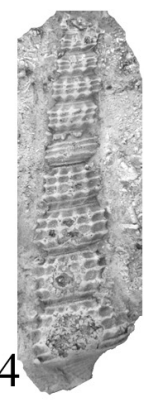

35

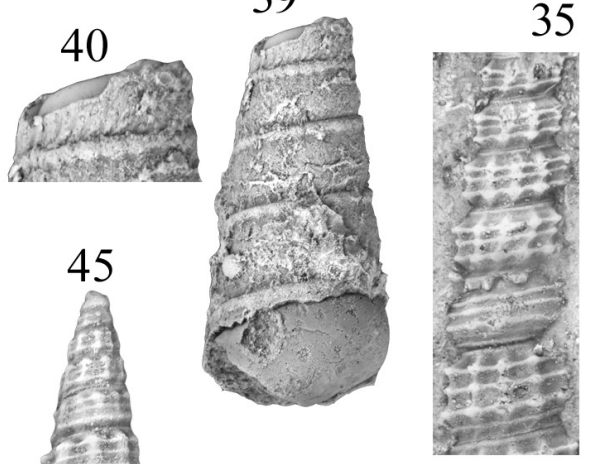

44
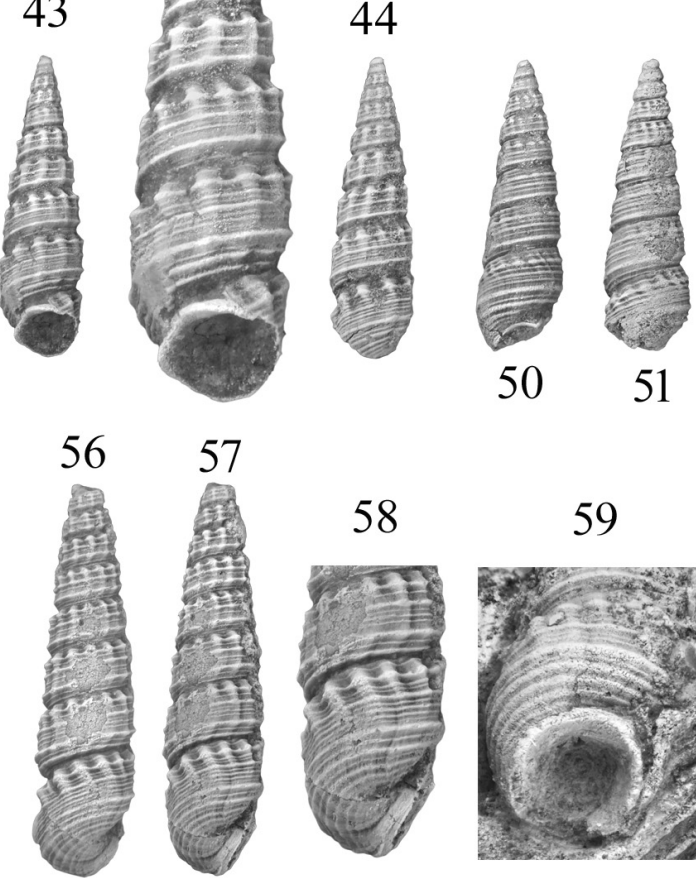

58

59
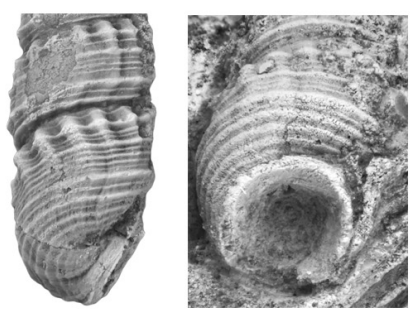
in Exelissa are bicarinate. Since the shape of the teleoconch also corresponds to this genus, the Indian species is regarded also as Exelissa, in spite of the spiral ornament that has been said characteristically sparser.

The most similar species is Exelissa africana Cox, 1965 (?Bajocian); its description (Cox 1965, p. 157) matches well also to this new Indian species; their close phylogenetical relation is probable. The most prominent differences are in their shape: Exelissa indiana n. sp. has more turriculate shell with only slight trace of cyrtoconoidal coiling while, at least in the holotype, E. africana has marked, cyrtoconoidally coiled early shell that gives bullet-like outline for the shell. Specimens, similar to the figured paratypes of $E$. africana do not occur in the Kachchh material. The shape and measurements of Exelissa (?) preralpina Cossmann, 1905 as figured by CossmanN (1913, p. 120, Pl. 5, Figs 15-16) are similar to those of Exelissa indiana but differ in having a third marked and nodosed cord in mid-whorl position.

Occurrence - Khadir Island, Gadhada Formation, Lower Callovian.

\section{Exelissa aff. strangulata (d'Archiac, 1840)}

(Figs $60 \mathrm{~A}-\mathrm{E}, 61-63$ )

aff. 1843 Cerithium strangulatum d' Archiac - p. 382, Pl. 31, Fig. 4.

aff. 1913 Exelissa strangulata (d'Archiac, 1840) - CossmanN, p. 116, pl. 5, Figs 42-45.

Material - Five poorly preserved specimens are available on a naturally prepared rock surface; they seem to be outer casts of shells.

Measurements - Inv. No.: BHU2020I 300 (B in Fig. 60); $\mathrm{H}$ dam. $=8.4 \mathrm{~mm}$; Inv. No.: BHU2020I 301(D in Fig. 60); H dam. = 7.4 mm; Inv. No.: BHU2020I 302 ( $\mathrm{F}$ in Fig. 60); $\mathrm{H}$ dam. $=10.6 \mathrm{~mm}$.

Description - The specimens are rather high and consist of an acute early teleoconch, followed by cylindroconoidal later shell parts. Last whorl is downward and adaxially inclined. In latest growth phase, parietal and columellar lips are detached from the base and grown leftward beyond shell axis. Sparse, orthocline and straight, suture to suture ribs $(\operatorname{six} \pm 1)$ give the transverse ornament; no trace of spiral ornament can be observed on the shells, neither growth lines are visible.

Remarks - The appearance of the shells are reminiscent of the type species and to Exelissa? sp. (see below). However, the specimens of Exelissa aff. strangulata are slenderer with suture to suture ribs that are more marked than in $E$. strangulata, and seemingly lack any kind of spiral ornament. These differences could be specific distinctive characters but shells are necessary for a more reliable identification.

Occurrence - Khadir Island, Ghadada Formation, Lower Callovian 


\section{Exelissa? sp.}

(Figs 64-65)

Material - A single specimen, combination of imprint and cross section of whorls on a broken rock surface.

Measurements - Inv. No.: BHU2020I 303; H dam. $=4.2 \mathrm{~mm}$.

Description - The remnants indicate a pupiform/bottle shaped, moderately turriculate shell. Its earliest preserved part shows a single whorl with rounded surface, perhaps it is (part of) the protoconch then two whorls of pagodiform outline with a keel on their angulation follow. From the third preserved whorl, a second keel also appears subsuturally; subsequently the whorls remain convex but lose their pagodiform nature. The bicarinate whorl surface lasts to the latest preserved whorl (? last whorl); two new spiral threads also develop on this shell part, one between the primary carinae and another one just above the suture. Together with the second carina, straight, prosocline ribs also appear and extend from suture to suture. Estimated number of these ribs is six $( \pm 1)$ per whorl. The ribs are aligned to each other on the neighbouring whorls; their rows are prosocline on the early teleoconch and form apparently twisted ridges around the axis then become more or less orthocline. Remains of the base show several spiral threads as ornament. No growth lines are observable.

Remarks - The genus name Exelissa? seems to approach the right systematic place of this species. However, the rather low spire with pupiform shell outline and "twisted" shell parts in early growth stage occurs also in Cryptaulax or in Xystrella. Well preserved material with protoconch and peristome is needed to find the correct generic position.

Occurrence - Ler, Chari Formation, Callovian.

Superfamily ?Cerithioidea Fleming, 1822

Cerithioidea? sp.

(Figs $60 \mathrm{G}, 66$ )

Material - Single specimen, a poorly preserved natural cast of sediment on weathered rock surface.

Measurements - Inv. No.: BHU2020I 304; $\mathrm{H}$ dam. $=11 \mathrm{~mm}, \mathrm{D}=2.4 \mathrm{~mm}$.

Description - A turriculate shell is available without the apical shell parts. The earliest preserved whorls are apparently concave but the latest two whorls have convex surface. On the last whorl, an abaxially extended peristome is visible that has also a short, straight siphonal protrusion in axial position with a leftward oriented siphonal notch.

Remarks - The preservation of this specimen allows only to give an indication about a species that is probably a caenogastropod. Inflation of the last 
whorl and extension of the last peristome with true siphonal outlet occur since the Triassic in different caenogastropod families.

Occurrence - Khadir Island, Ghadada Formation, Lower Callovian.
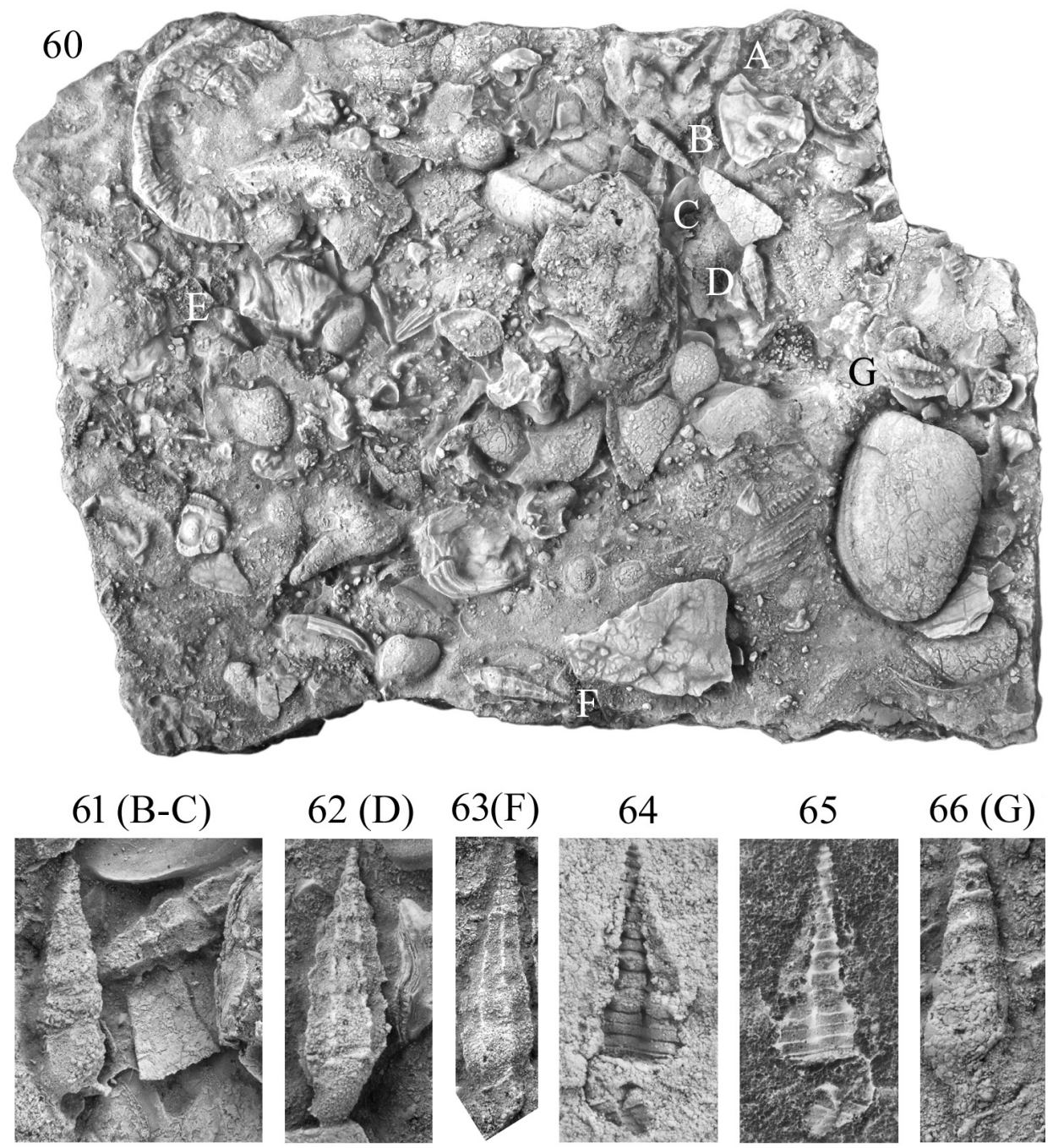

Figs 60-66. Caenogastropods 2. - Fig. 60. A piece of naturally prepared bed plane with a fossil assemblage, containing also new species for the Kachchh Callovian fauna; letters indicate position of the gastropod specimens. - Figs 61-63. Exelissa aff. strangulata (d'Archiac, 1840). - 61. Apertural view, ×4.4. - 62. Abapertural view, $\times 5$. - 63. Apertural view, $\times 3.5$. - Figs 64-65. Exelissa? sp, $\times 8.8$. - 64. The original view on another broken rock surface. -65 . A variety of Fig. 64, to make it more digestible through reflection, and inversion of colour. - Fig. 66. Cerithioidea? sp., a poorly preserved specimen, indicating a siphonostomatous species, also new for the Callovian fauna of Kachchh, $\times 3.4$ 
Superfamily Purpurinoidea Zittel, 1895

Family Purpurinidae Zittel, 1895

Genus Purpurina d'Orbigny, 1850

Type species - Purpurina bellona d'Orbigny, 1850

Purpurina sp.

(Figs 76-77)

Material - Single, fragmentary specimen.

Measurements - Inv. No.: BHU2020I 305; H dam. $=14.2 \mathrm{~mm}$.

Description - A badly worn specimen is available that suggests a moderately high spired Purpurina species with a narrow ramp and rather high outer face of the whorls. Marked, equally sized cords compose the spiral ornament that is crossed by sparse, low, collabral ribs/undulations.

Remarks - The poor preservation does not allow reliable species level identification.

Occurrence - Jhura Dome, Chari Formation, Callovian.

Superfamily Stromboidea Rafinesque, 1815

Family Alariidae Koken, 1889

Genus Diarthema Piette, 1864

Type species - Pterocera paradoxa J. A. Eudes-Deslongchamps, 1843

Diarthema sp.

(Figs 67-74)

Material - Two deformed specimens, both are adaxially compressed inner moulds, bearing also badly worn shell fragments.

Measurements - Inv. No.: BHU2020I 306 (Figs 67-70); H dam. = $15.3 \mathrm{~mm}$; Inv. No.: BHU2020I 307 (Figs 71-74); H dam. = $14.2 \mathrm{~mm}$.

Description - Moderately high, few-whorled ( 5), pagodiform shells with low spire and blunt apex. The earliest whorl (= protoconch?) seems nearly planispiral then the earliest teleoconch whorl has rounded surface, and about three whorls of the teleoconch with marked spiral angulation follow it. A rather wide, abapically-abaxially, mildly sloping ramp and an abapically-adaxially sloping outer face compose the whorl surface. Both the ramp and the outer face are just slightly convex or flat. For the last whorl, the angulation vanishes and the slightly convex whorl surface passes to the highly conoidal base without distinct limit. Suture is well impressed. Remnants of the latest inner lip indicate an obliquely elongated peristomal complex. Its abapical part extends left well beyond the axis and has the shape of a siphonal notch. The adapical part extends up to the ramp/ upper suture area on the initial last whorl and probably also to the outer face of 
the penultimate whorl as some remnants indicate it. The inner lip between the two terminal parts appears as rather thick callus on the base.

Ornament is visible on the last three whorls of both specimens as sparse spiral cords of unequal thickness and dense, transverse riblets, which have been hollow internally or the shell itself has been substituted by sediment; the riblets become gradually stronger (ribs); they extend from suture to suture. Together with this ornament, the angulation of the whorls also developed. The spiral ornament elements last to the peristome as sparse and sharp cords and keels but, after reaching their strongest form on the penultimate whorl, the periodically repeated ribs are already lacking. On the last whorl, only few varices are the transverse ornament, showing the places of former, not periodically grown, extended peristomes.

Remarks - The two specimens significantly differ from each other; they seem to belong to a highly variable species. However, the specimen in Figs 71-74 resembles also Struthiolaria and the poorly preserved sharp ridge that seems to be the edge of a former outer lip, shown in Fig. 73, supports its place in Diarthema but perhaps in different species. Well-preserved material is needed to a more accurate identification. No species has yet been found in the literature that would show close similarity to these specimens.

Occurrence - Habo Dome, Pacham Formation, Bathonian.

Genus Cuphotifer Piette, 1876

Type species - Rostellaria hamulus J. A. Eudes-Deslongchamps, 1843

Cuphotifer? sp.

(Fig. 75)

Material - Single specimen with re-crystallised shell, without earliest and latest whorls.

Measurements - Inv. No.: BHU2029I 308; H dam. $=3.5 \mathrm{~mm}$.

Description - The remnants indicate a turriculate shell, consisting of convex whorls; the highest line of the convexity is at about the abapical third of the distance between the sutures; this line corresponds to the periphery. Impressed suture separates the whorls. Abapically, a ribbon-like spiral elevation accompanies the suture together with a narrow, shallow concavity below it.

The earliest preserved whorl bears sparse, nearly suture to suture, sharpened node-like, collabral riblets, which gradually shorten during the growth and become a row of dome-like true nodes along the top of convexity of the last whorls.

The growth lines are opisthocyrt and slightly opisthocline.

Remarks - This shell clearly indicates a species that is different from the coeval ones, however, the preservation does not permit more accurate identification. Similarly arranged ornament, riblets on early whorls that alter into peripheral nodes 
on more or less turriculate shell with opisthocyrt growth lines, occurs in some stromboidean genera like Aporrhais, Cuphotifer, Trietteia, etc. Since Cuphotifer (= Pietteia) species have been already found in the Middle Jurassic faunas of Kachchh (JaItly \& Szabó 2007), tentatively this genus name is given now. By BANDEL (2007, p. 102), Pietteia Cossmann, 1904 is a junior synonym of Cuphotifer.

Occurrence - Habo Dome, Patcham Formation, Callovian.

Subclass Heterobranchia Gray, 1840

Superfamily Actaeonoidea d'Orbigny, 1843

Family Aplustridae Gray, 1847 (Bullinidae Gray, 1850)

Genus ?Parvulactaeon Gründel, 1997

Type species - Parvulactaeon spiralocostata Gründel, 1997

\section{Parvulactaeon? sp.}

(Fig. 78)

Material - A poorly preserved, fragile specimen.

Measurements - Inv. No.: BHU2029I 309; H dam. $=4.3 \mathrm{~mm}, \mathrm{D}=2.8 \mathrm{~mm}$.

Description - Four teleoconch whorls are available that form a slightly gradate shell. Suture is impressed and accompanied by an indistinct subsutural ramp. Below the ramp, slightly convex whorl surface is formed that smoothly turns into the subglobular base in the last whorl. No information is accessible about the peristome; on the broken apical shell surface, the shell seems anomphalous.

The shell surface has "bulliniform" ornament, i.e. subequally distributed spiral striae cut the surface into nearly uniform strips. No growth lines are observable.

Remarks - In lack of the earliest and latest shell parts, bearing crucial information for a right identification, only the open nomenclature remained, which is based on the general shape. Similar sized and constructed shells are found in Aplustridae and Parvulactaeon is the genus, which may have similar subsutural ramp. Actually, this species may belong even to different family on the basis of the unknown protoconch and peristome characters. Species level identification needs also further specimens and studies.

Occurrence - Fakirwari, Chari Formation, Callovian.

Genus ?Sulcoactaeon Cossmann, 1895

Type species - Actaeonina striatosulcata Zittel et Goubert, 1861

Sulcoactaeon? haboensis n. sp.

(Figs 80-83)

Type specimen - Holotype Inv. No.: BHU2020I 310.

Type locality - Habo Dome. 
Type strata - Patcham Formation, Bathonian.

Derivation of name - Refers to the locality.

Diagnosis - Bulliniform shell with single visible whorl of coaxial protoconch, and teleoconch whorls, having narrow, concave, subsutural ramp with sharp rim. Aperture elongated, leftward extending beyond axis in basal region. Peristome interrupted but thin inductura smoothen parietal wall. Outer and basal lip outward tapering. Columellar/umbilical lip arched and externally sharply angular; its widened inner surface hidden in normal apertural view since nearly perpendicular to plane of peristome. Hidden part having median furrow, possibly containing also narrow opening of umbilicus at its adapical end. Whole teleoconch, excepting ramp, ornamented by sparse spiral striae with ribbons in interspaces; few differently strong threads occurring along and on external part of columellar/umbilical lip.

Material - Single, rather well-preserved specimen.

Measurements - Inv. No.: BHU2020I 310; $\mathrm{H}=5.5 \mathrm{~mm}, \mathrm{D}=3.1 \mathrm{~mm}$.

Description - A minute, ovate shell of 4.5 visible whorls with impressed suture represents this species. The first whorl, which that is almost planispiral, convex and seemingly smooth, yet belongs to the protoconch, which is apparently coaxial with the teleoconch. A marked growth line indicates beginning of the teleoconch, which has a narrow, slightly concave ramp with a clear angulation as abaxial rim. The convex outer face of the whorls turns into the convex base without boundary. The peristome and aperture are subaxially elongated and extend higher than half of the full shell and have left side concave water drop shape. The outer lip is thin, outward tapering and smoothly arched to the basal lip, which continues as a sharp outer rim of the columellar/umbilical lip then terminates at the parietal wall. Major part of the columellar lip is hidden behind the sharp frontal edge; it is rather wide and nearly perpendicular to the plane of the peristome; in axial direction, it is slightly concave adaperturally, and has also a vertical furrow, perhaps with a narrow opening for a possible umbilicus. No trace of columellar or parietal folds is observable.

Figs 67-83. Further caenogastropods and some acteonoideans. - Figs 67-74. Two deformed specimens of Diarthema sp. - 67-70. BHU2020I 306 specimen in apical, flattened apertural, abapertural views, and an image parallel to the compressed aperture, $\times 3.9$. - 71-74. BHU2029I 307 specimen in apical, "apertural", "abapertural", and in peristome plane views, ×4.2. - Fig. 75. Cuphotifer? sp., the only informative view, $\times 10$. - Figs 76-77. Purpurina sp. in apertural and abapertural positions, $\times 2.8$. - Fig. 78. Parvulactaeon? sp., the most informative view, $\times 7 .-$ Fig. 79. Mathilda? sp. on loose matrix surface, $\times 8.7$. - Figs 80-83. Sulcoacteon haboensis n. sp., holotype. - 80-82. Apertural, abapertural and apical views; oblique apertural view, $\times 7.3$. -83 . Inner face of columellar lip, bearing also vertical fissure of umbilicus, $\times 7.3$; Fig. 80 shows outline of the entire, very thin outer lip and the shape of the aperture. This outer lip suffered subsequently damages (Fig. 83) during the cleaning of the inner lip region, bearing diagnostic characters 


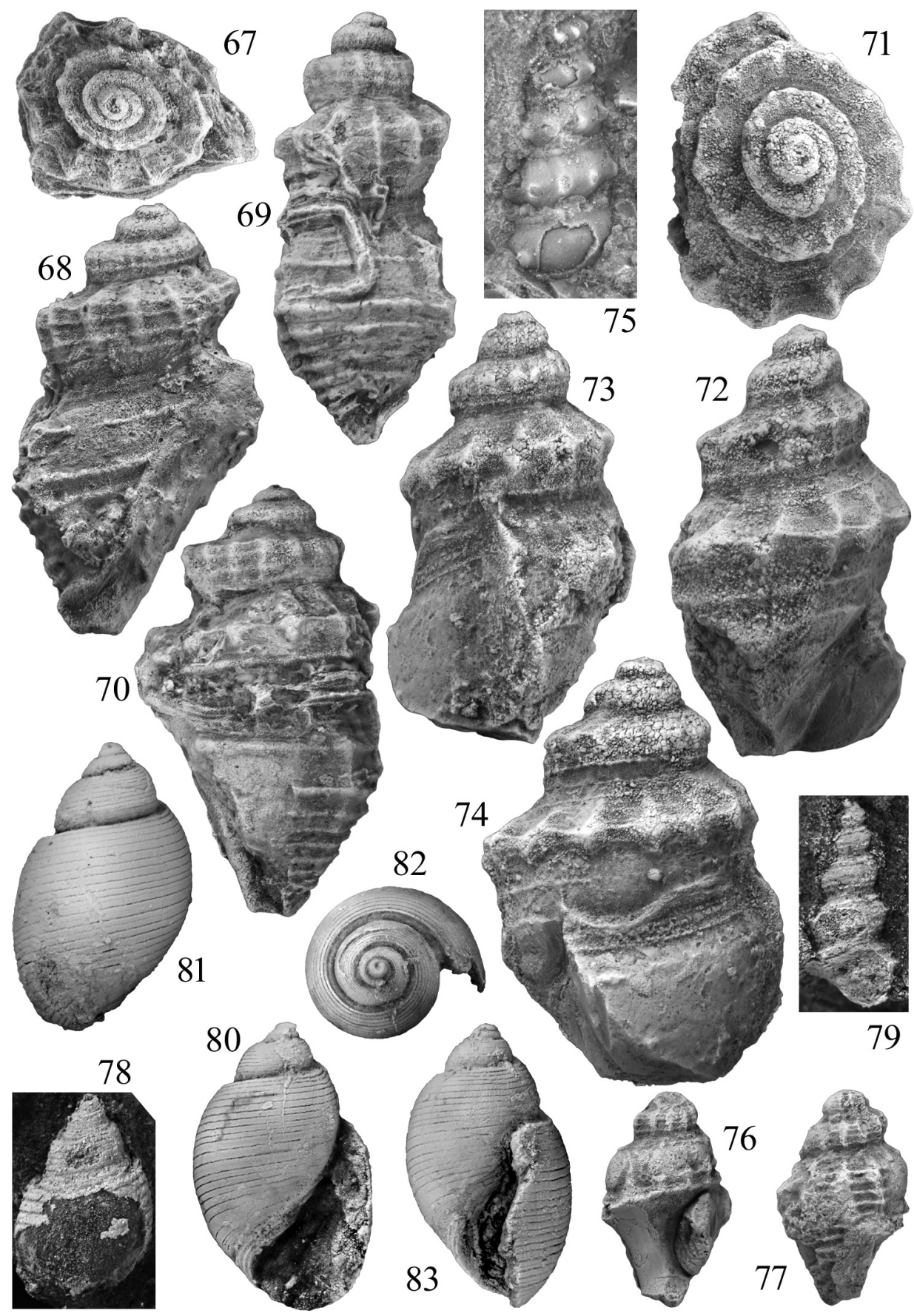


The first whorl, which belongs to the protoconch is smooth but, excepting the ramp, the teleoconch is sparsely striated along its full length; the striae separate nearly equally wide ribbons. Other ornament appears only on and along the outer rim of the columellar/umbilical lip as differently strong spiral threads of inequal length. The growth lines have nearly orthocline orientation and asymmetrically prosocyrt shape; near the ramp, their arch is narrower than elsewhere. Growth lines of the ramp are opisthocline and opisthocyrt.

Remarks - The striae of the shell are filled by unremovable sediment. However, short rim pieces of the ribbons show subregular undulations that may indicate pitted nature of the striae.

The species of Sulcoactaeon have frontally exposed columellar or umbilical lip and in this feature, they differ from the Kachchh specimen that has a new type of inner lip. It remains a question whether this inner lip bears only species or even generic level distinctive meaning; that is why the question mark is added to the genus name.

Occurrence - Habo Dome, Patcham Formation, Bathonian.

Superfamily Architectonicoidea Gray, 1850

Family Mathildidae Dall, 1865

Genus ?Mathilda Semper, 1865

Type species - Turbo quadricarinatus Brocchi, 1814

Matbilda? sp.

(Fig. 79)

Material - Single, fragmentary specimen.

Measurements - Inv. No.: BHU2020I 311; H dam. $=3.5 \mathrm{~mm}, \mathrm{D}=1.8 \mathrm{~mm}$.

Description - Minute, turriculate shell without apical and latest shell parts. The shape of the preserved whorls is quite characteristic; they have a wide, slightly convex subsutural ramp, abaxially limited by a nearly mid-whorl angulation; the remaining part of the whorls actually also form ramp that slopes adaxially towards the lower suture.

The angulation between the ramps bears a carina, further double spiral threads are above and below it; no more ornament, neither growth lines are preserved.

Remarks - The shell is characteristic enough to place it in Mathildidae but poorly preserved for accurate identification.

Occurrence - Fakirwari, Chari Formation, Callovian.

\section{CONCLUSIONS}

In spite of the not really abundant and well-preserved material on hand, this paper can contribute to the knowledge of the Jurassic faunas of Kachchh 
with new data in a broad scale of Gastropoda (Vetigastropoda, Neritimorpha, Caenogastropoda, and Heterobranchia). Perhaps the most important information is connected to Cerithioidea since no former paper on the Jurassic faunas of Kachchh contains taxonomical details of this group. On lower taxonomical levels, presence of Jumaramaria n. gen. is remarkable since its morphological features are unique in all families of Pleurotomariina. Jumaramaria belongs to those few genera, which do not occur in the much more deeply studied "stable" European, neither in the Mediterranean/Inner Tethyan Jurassic faunas.

Acknowledgements - The studied gastropods were collected during lots of field trips mainly in the period between 1989 and 1999. We are thankful to the participants who are collectors of many specimens that are objects of this paper: M. Aberhan (Berlin), J. H. Callomon (London), F. T. Fürsich, M. Heinze, S. Schlirf, M. Schlirf (Würzburg), W. Oschmann (Frankfurt), D. K. Pandey (Jaipur), and I. B. Singh (Lucknow). We thank also to Mr. B. H. Bhatti (Bhuj) for the helps to realization of these field works. Many thanks to A. V. Guzhov (Moscow) and to B. Erdei (Budapest) for the thorough review of the manuscript.

\section{REFERENCES}

Alberti M., Nützel A., Fürsich F. T. \& Pandey D. K. 2013: Oxfordian (Late Jurassic) gastropods from the Kachchh Basin, western India. - Neues Jahrbuch für Geologie und Paläontologie - Abhandlungen 270(3): 275-300. https://doi.org/10.1127/0077-7749/2013/0370

Archiac A. D' 1843: Description géologique du département del'Aisne. - Mémoires de la Société géologique de France [1], 5(2): 129-419, Pls 21-31.

BANDEL K. 2007: Description and classification of Late Triassic Neritimorpha (Gastropoda, Mollusca) from the St Cassian Formation, Italian Alps. - Bulletin of Geosciences 82: 215-274. https://doi.org/10.3140/bull.geosci.2007.03.215

Cossmann M. 1885: Contribution à l'étude de la faune de l'étage bathonien en France (Gastropodes). - Mémoires de la Société Géologique de France [3], 3(3): 1-374.

Cossmann M. 1906: Essais de paléoconchologie compare. - Paris, 7: 1-261, Pls 1-14.

Cossmann M. 1913: Contribution a la Paléontologie francaise des Terrains jurassiques. III. Cerithiacea et Loxonematacea. - Mémoires de la Société Geologique de France 19(3-4): 1-88, Pls $1-4$.

Cox L. R. 1965: Jurassic Bivalvia and Gastropoda from Tanganyika and Kenya. - Bulletin of the British Museum (National History), Geology, Supplements 1: 1-213.

DAS S. S. 2007: Record of a new species of Obornella Cox, 1959 (Gastropoda) from the Tithonian of Kutch, western India. - Journal of Asian Earth Sciences 30: 207-212. https://doi.org/10.1016/j.jseaes.2006.07.016

DAs S. S. 2008: Gastropod diversity patterns and evolutionary tempo during the early rifting phase (Jurassic) of the Kutch Basin. - Journal of the Palaeontological Society of India 53(1): 9-18.

DAs S. S., BARDhAN S. \& KASE T. 2005: A new pleurotomariid assemblage from the Jurassic sequence of Kutch, western India. - Paleontological Research 9(4): 329-346.

https://doi.org/10.2517/prpsj.9.329 
DAS S. S., BARDHAN S. \& LAHIRI T. C. 1999: The Late Bathonian gastropod fauna of Kutch, Western India - a new assemblage. - Paleontological Research 3(4): 268-286.

Das S. S., Mondal S., Saha S., Bardhan S. \& Saha R. 2019: Family Naticidae (Gastropoda) from the Upper Jurassic of Kutch, India and a critical reappraisal of taxonomy and time of origination of the family. - Journal of Paleontology 93(4): 673-684.

https://doi.org/10.1017/jpa.2019.3

Das S. S., SaHA S., Bardhan S. \& Mallick S. 2018: The oldest turritellinae gastropods from the Oxfordian (Upper Jurassic) of Kutch, India. - Journal of Paleontology 92(3): 373-387. https://doi.org/10.1017/jpa.2017.89

FisCHER J.-C. 1969: Géologie, paléontologie et paléoécologie du Bathonian au Sud-Ouest du Massif Ardennais. - Mémoires du Muséum national d'Histoire naturelle [C], 20: 1-319, pls 1-21.

Guzhov A. V. 2004: Jurassic gastropods of European Russia (orders cerithiiformes, bucciniformes, and epitoniiformes). - Palaeontological Journal 38: 457-562, Suppl. 5.

Hébert M. \& Eudes-Deslongchamps E. 1860: Mémoire sur les fossiles de Montreuil-Bellay (Maine-et-Loire), 1 re partie. Céphalopodes et Gastéropodes. - Bulletin de le Société Linnéenne de Normandie 5: 153-240.

JAitly A. K., Szabó J. \& FÜRSICH F. T. 2000: Contributions to the Jurassic of Kachchh, western India. VII. The gastropod fauna. Part I. Pleurotomarioidea, Fissurelloidea, Trochoidea and Eucycloidea. - Beringeria 27: 31-61, 3 text-figs, 6 pls.

Jaitly A. K. \& Szabó J. 2002: Bhujnerita (Neritidae), a new gastropod genus from the Kachchh Jurassic (western India) - Fragmenta Palaeontologica Hungarica 20: 49-52.

JAitly A. K. \& SzABó J. 2007: Contributions to the Jurassic of Kachchh, western India. The gastropod fauna. Part III: further Caenogastropoda and Opisthobranchia. - Fragmenta Palaeontologica Hungarica 24-25: 77-82.

Knight J. B., Cox L. R., Keen A. M., Smith A. G., Batten R. L., Yochelson E. L., Ludbrook N. H., Robertson R., Yonge C. M. \& Moore R. C. 1960: Mollusca-General features, Scaphopoda, Amphineura, Monoplacophora, Gastropoda-General features, Archaeogastropoda and some (mainly Paleozoic) Caenogastropoda and Opisthobranchia - In: Moore R. C. \& Pitrat C. W. (eds): Treatise on Invertebrate Paleontology, Part I, Mollusca 1. - The University of Kansas Press, Lawrence, XXIII+351 pp.

Maithani J. P. B. 1968: Some new species of the Jurassic gastropods and lamellibranchs from the Habo Dome, Kutch and their usefulness in correlation. - Records of the Geological Survey of India 95: 491-524.

Mitra K. C. \& Ghosh D. N. 1979: Jurassic turritellas from Kutch, Gujarat. - Quarterly Journal of the Geological Mining and Metallurgical Society of India 51: 119-122.

Pandey B., Pathrak D. B., Jaitly A. K., Krishna J., \& Venkateshwarlu M. 2012: Record of Tethyan gastropod genus Asterohelix Szabó, 1984 from Late Bajocian (Middle Jurassic) of Kachchh, Western India. - Indian Journal of Geosciences 66: 65-68.

Sowerby J. DE C. 1840: Description of fossils from the Upper Secondary Formation of Cutch collected by C. W. Grant. - Transactions of the Geological Society of London [2], 5: Explanation of pl. 21, figs. 8-17; pls. 22-23

Szabó J. \& Jaitly A. K. 2004: Contributions to the Jurassic of Kachchh, western India VIII. The gastropod fauna. Part II: Discohelicidae, Neritomorpha, Caenogastropoda. - Fragmenta Palaeontologica Hungarica 22: 9-26. 